\title{
A109 垂直軸型風車の性能予測と流れの可視化に関する研究
}

\author{
A Study on Flow analysis and Performance of Straight Wing Vertical Axis Wind turbine
}

\author{
正 堀内健司(IRD) 相良啓太(IRD) 正 関和市(明道大)
}

Kenji HORIUCHI, IRD Co.,Ltd., 576-4 Fujisawa, Fujisawa-shi, Kanagawa 251-0052

Keita SAGARA, IRD

Kazuichi SEKI, Mingdao Univ.

\begin{abstract}
We have started the research of application for comprehensive wind energy since 1976. The research has continued for more than thirty years. The topics of the research include the design of best suitable turbines, wind characteristics, wind energy density and reserve, the efficiency of the wind power system, etc.

Both the Straight Win Fixed Pitch Vertical Axis and the Horizontal Axis wind power systems have done the wind tunnel experiments and field tests. The research results also cover the relevant running tests, determination of the boundaries, stress tests in limits, etc.

This report is the summarized statement for the most up-to-date experimental results of the Straight Wing Vertical Axis Wind Turbine power system.
\end{abstract}

Key Words: Vertical Axis Wind Turbine, Performance, Field Experiment, Solidity

\section{1. 緒 曹}

1976 年から 30 年間にわたって、風力利用システムに関す る研究を行っている。これらの成果は、風車用最適翼型の開 発、風況特性と風エネルギー密度抢よび賦存量に関する研究、 風車の性能にする研究、直線翼固定ピッチ垂直軸および水平 軸風車の開発を行い、風洞実験とフィールド実験、運転と保 守に関寸る研究、運用限界の設定に関する研究、疲労限界に 関する研究、保安系統に関する研究、実風況下 (風速変動下) での風車運用シミュレーションの研究、風車のプロダクトサ ポートに関する研究、実風況下での風車効率の算出、大型水 平軸風車のロータブレードの効率向上と低騒音化に関する 研究、山岳高地用小型風力発電システムの研究、航空障害灯 用電源システムに関する研究、ダウンウィンドロータに関す る研究等の多くの研究開発成果が得られた。本報告は直線翼 垂直軸風車の実用化に関する実験的研究を行ったものであ る。非周期制御方式の掦力型 SW-VAWT の特徴は、固定ピッ チで高い周速比で大きなトルクを得られ、したがって効率が 良く機構的にも簡明である。平面型は直線翼である。

本実験的研究は、非周期制御方式の直線翼固定ピッチ垂直 軸風車発電システムについて述べたものである。

\section{2. 直線翼垂值軸型風力発電システムの特徵}

図2.1に1976年から現在までの直線翼垂直軸風力発電シス テムを示す。直線翼垂直軸型風力発電システムは固定ピッチ 方式であるので構造的に簡略である。直線翼垂直軸型風力発 電システムでは值線翼であるので、遠心力による曲げ応力を 受けるが、翼を直線状にしたことから効率が高い。風車サイ ズが大きくなると、回転数が下がるので遠心力が小さくなる。 したがって、大規模な風車は、直線翼型が有利である。関1) 2) 3)によって開発された直線翼垂直軸型風力発電システムは、 自己起動が可能である点が挙げられる。

最も重要な特徵の一つとして、他の垂直軸型風車は、翼断面 型を対称翼としているのに対して、関 ${ }^{4)}$ が開発研究した直線 翼垂直軸型風力発電システムは、独自に研究開発した TWT
系翼型を用いていることである。この TWT 系翼型の特徴は、 直線翼垂直軸型風力発電システムの始動起動性を良好にし、 高周速比では、高い効率を得ることが可能である。

本風車システムは、空気力学的性能、構造材料および制御 システムに関する実験と変換における最適負荷制御につい ての実験を中心に行っているものである。

\section{3. 直線翼垂直軸風車システムの応用例}

\section{1 風力・太陽光ハイブリッド発電システム}

風力発電システムは直線翼垂直軸型風力発電システムで ある。図 3.1 に示す。風車受風面積が $1.0 \mathrm{~m}^{2}$ で、風車直径 $1.0 \mathrm{~m}$ 、 翼長 $1.0 \mathrm{~m}$ 、翼断面型は TWT 翼型を用いている。年平均風速 $0.7 \mathrm{~m} / \mathrm{s}$ から発電し、風速 $12.5 \mathrm{~m} / \mathrm{s}$ で定格出力 $300 \mathrm{~W} ゙$ ある。 発電機出力は充電制御器により直流に変換されて蓄電池に 充電される。太陽電池システムは、屋根およびタワーに取り つけた。風車は、予想を上回る発電をおこない、常時、蓄電 池が満充電である。蓄電池は、充電をおうさい街灯照明とし て利用している。照明は、高光度 LED を用いており、消費 電力が小さく、長寿命である。また、24VDC から 100VAC 一変換するためのインバータが備えられている。地震等の災 害、緊急時に $100 \mathrm{~V}$ の負荷の電源として用いることも利用可 能である。

\section{2 船舶用直線琶垂直軸型風力発電システム}

直線翼垂直軸型風力発電システムを木材チップ運搬船に 搭載し、船舶用直線翼垂直軸型風力発電システムとして、実 用化実験を行っている。図 3.2 は実験に用いた直線翼垂值軸 型風力発電システムである。風車受風面積が $5 \mathrm{~m} 2$ の SW-VAWT で、風車值径 $2.5 \mathrm{~m}$ 、翼長 $2.0 \mathrm{~m}$ 、翼断面型は TWT 翼型を用い ている. 定格出力は $3 \mathrm{~kW}$ である。発電機によって電気エネル ギーに変換し $100 \mathrm{VAC}$-単相 $-60 \mathrm{~Hz}$ で出力し、空調機器などに 応用し、最適負荷制御について実験を行っている。 


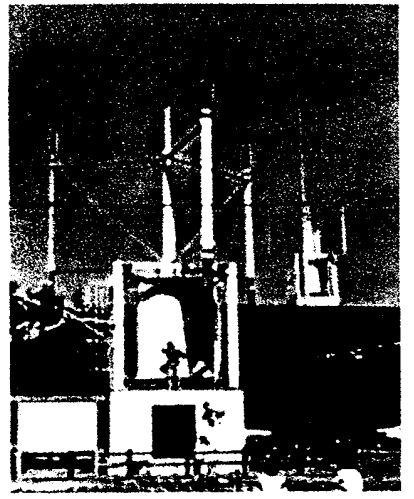

(a) 1981

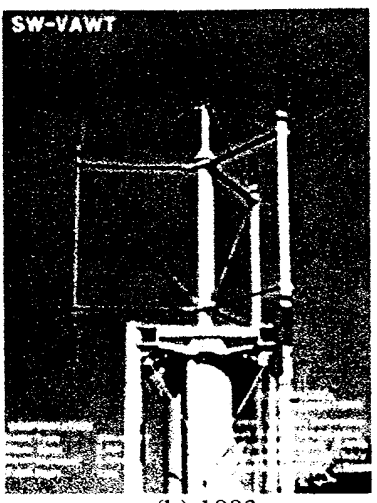

(b) 1982

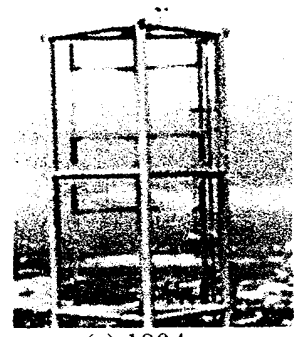

(c) 1984

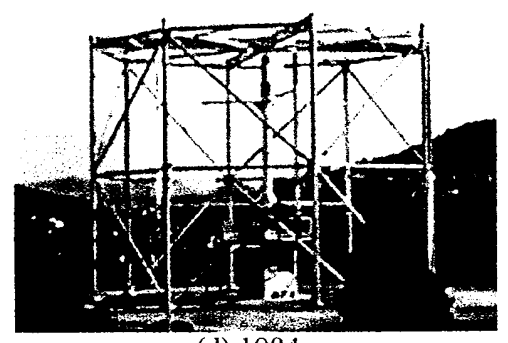

(d) 1984

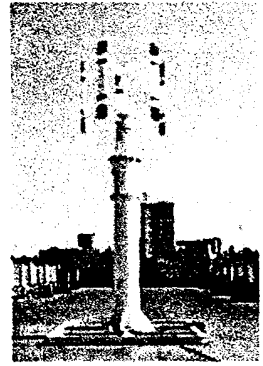

(e) 2000

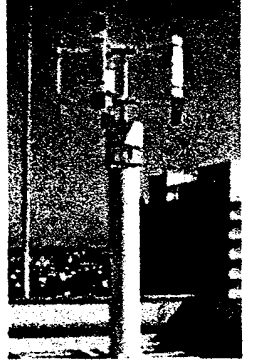

(f) 2002

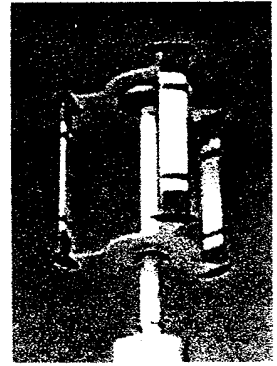

(g) 2002
Fig.2.1 SW-VAWT(1981-2002)

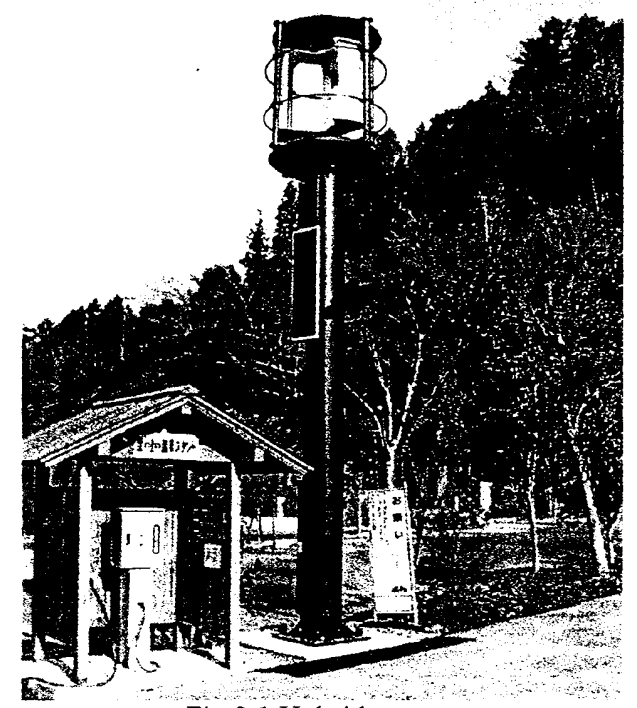

Fig.3.1 Hybrid system
ブリッジ右舷側に風力発電装置を設置し、右舷のウイング 下側に制御室、バッテリー室があり、各々制御盤およびバッ テリーを収納している。さらにブリッジ内に負荷用の空誦機 器および運転制御システムと運転データを記録するデータ 収集システムを設置した。また、ブリッジ上のコンパスデッ キに風向風速計を設置した。

実験航海は、2004 年 3 月 10 日に、オーストラリアのイー デンに出航した。日本近海から赤道付近までは風速 $10 \mathrm{~m} / \mathrm{s}$ 以 上であり、良好な実験結果が得られている。赤道付近から追 い風を受け、見かけ上無風状態が観測された。また、低気压 が発生しやすい海域であり、風向、風速が不安定であった。 イーデン近傍でサイクロンが接近した。

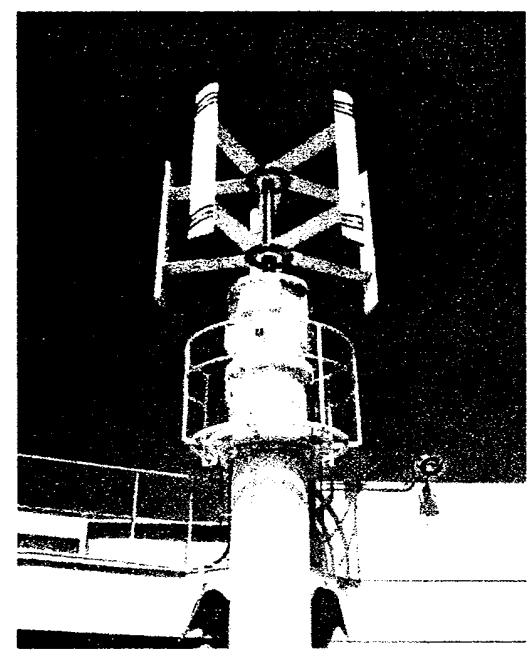

Fig.3.2 SW-VAWT for marine application

3.3 直線翼垂直軸型潮流発電システム

直線翼垂直軸型潮流発電システムを図 3.3 に示した。「直 線翼垂直軸型水流発電システム」は鉛直回転軸のまわりに複 数の直線翼を固定して持つことを特徽とし，シンプルな構造 で高い変換効率を有している。室内実験, 現地実証実験を行 い, 安定性, 発電性能を検討した。室内にて潮流を模擬した 曳航実験を静水中において行い，潮流により水車に作用する 荷重について基本的な特性を把握した。さらに兵庫県南あわ じ市南淡町において, 流速, 回転数などの現地実証実験を行 った。

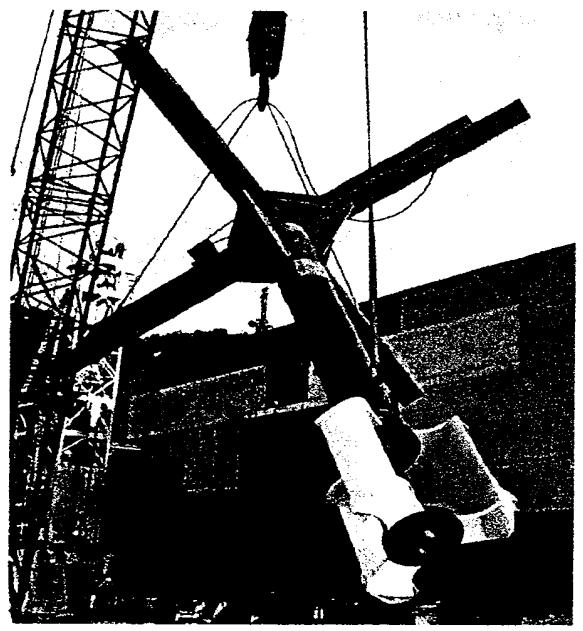

Fig.3.3 SW-VAWT which used a tide 
実海域実験は受水面積が $1 \mathrm{~m} 2$, 水車直径 $1.0 \mathrm{~m}$, 翼長 $1.0 \mathrm{~m}$ 翼 断面型は TWT 翼型を用いた。流向は 250 度方向に卓越する ものの全方向に分布しており，上潮・下潮といった単純な 2 方向の流れではなく，実験海域の地形特有の流況であった。 流速は最大 $0.6 \mathrm{~cm} / \mathrm{sec}$ 程度まで出現した。流速 $0.25 \mathrm{~m} / \mathrm{sec}$ 程度 から水車が回転し始め，これに合わせて水車軸トルクが発生 している。実験計測值は計算值の周囲に分布し，良い一致を 示している。

\section{4 寒冷港湾域における直線翼垂直軸型風力発電システム}

図 3.4 は実験に用いた直線翼垂直軸型風力発電システムで ある。稚内市宗谷港内に設置したもので、風車受風面積が $5 \mathrm{~m}^{2}$ で、風車直径 $2.5 \mathrm{~m}$ 、翼長 $2.0 \mathrm{~m}$ 、翼弦長 $0.30 \mathrm{~m}$ 、翼断面型は TWT 翼型を用いている. 発電機によって電気エネルギーに 変換し 100VAC で出力し、照明などに応用し、最適負荷制御 について実験を行っている。

本システムの直線翼垂直軸風力発電システムは、出力は年 間平均風速が $0.7 \mathrm{~m} / \mathrm{s}$ から発電を開始し、 $5 \mathrm{~m}^{2} \mathrm{SW}$-VAWT シス テムは、風速 $15 \mathrm{~m} / \mathrm{s}$ で最大出力 $4 \mathrm{~kW}$ 、強風時には、ロータの 過回転を防止する制動装置の作動を確認した。インバータに よって、100VAC に変換され照明等に用いた。

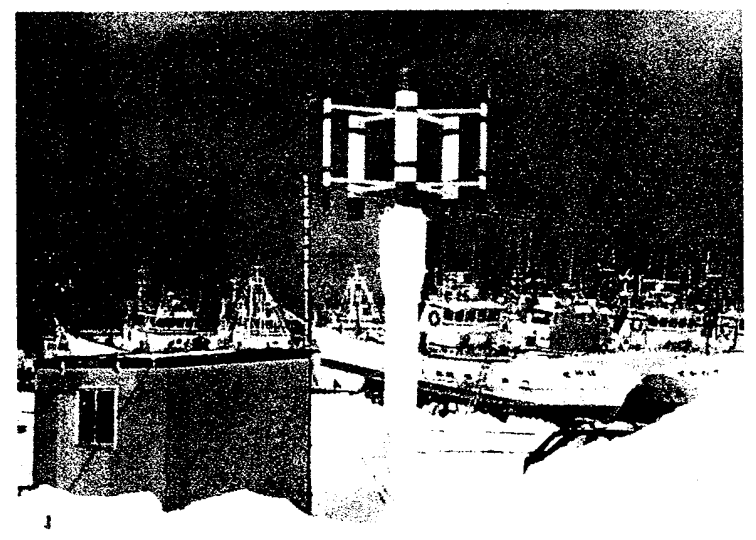

Fig.3.4 SW-VAWT which is installed in cold districts

気象条件の厳しい日本最北端宗谷岬の宗谷港湾の荷捌用 地で地域特性に適した新エネルギーの創出に対して、港湾: 親水施設等の照明、道路:道路照明等、農業:環境保全水に向け て、実験を行っている。特に、着雪・着氷・結水・塩害に 適した形状、構造、材料、制御および利用方法ついても、忘 用実験を行ったものである。

無風による風車回転停止状態において、降雪があった場合、 ブレード支持翼への積雪が観測された。図 12 に積雪時の直 線翼垂直軸型風力発電システムを示した。一方、実験を通じ て、ブレードに付着した海水による塩分によって、一層水着 しやすい状態になり、さらに積雪寒冷地特有の凍結が加わる と、ブレードを中心に氷塊になる可能性が推測される。本実 験において、無風による風車回転停止状態におけるブレード 支持翼への積雪㧍よび着氷は、遠心力で付着した雪氷を飛散 させたが、さらに無風降雪時の積雪および着水に対する観測 を継続する必要がある。さらにブレードは、全体に塩が付着 することが分かった。

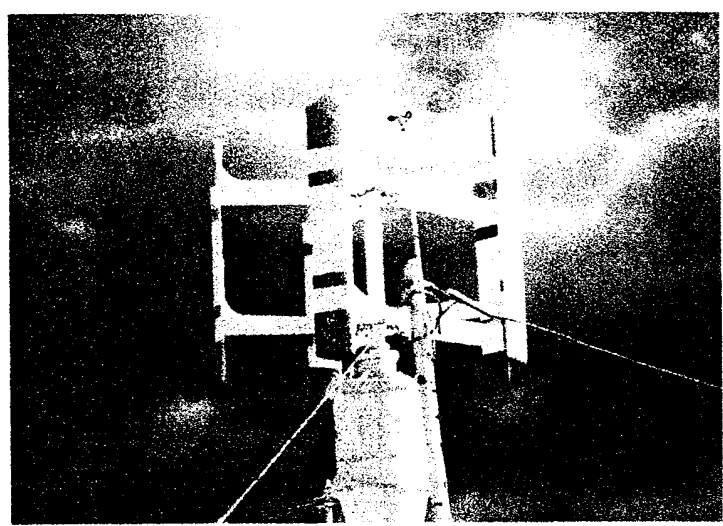

Fig.3.5 SW-VAWT which snow stuck to

3.5 地域における環境共生型直線翼垂直軸風力発電システム

図 3.6 の直線翼垂直軸型風力発電システムは、石川県中能 登町に設置したもので、風車受風面積が $5 \mathrm{~m}^{2}$ で、風車直径 $2.5 \mathrm{~m}$ 、翼長 $2.0 \mathrm{~m}$ 、翼断面型は TWT 翼型を用いている. 出力 は、100VACであり、照明等で実験を行っている。

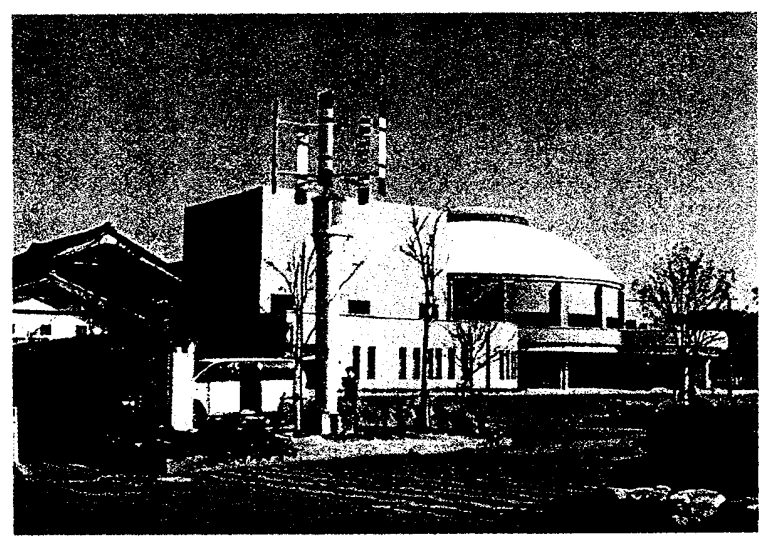

Fig.3.6 SW-VAWT which is aimed for symbiosis with environment

\section{4. 性能予測と流れ解析}

数值シミュレーション手法により風車部の流れ解析とそ の応用として性能予測した結果の抜粋を報告する。本研究の 数值解法を用いた直線翼垂直軸風車の流れ解析の応用とし て、開発されている実機についてフィールド実験により計測 された風車効率に対して、数值解法による直線翼垂直軸風車 の効率を計算し、比較を行って、数值解法を用いた直線翼垂 直軸風車の流体力学的特性推定方法の妥当性を明らかにし た。

トルク係数から風車効率 $\mathrm{Cp}$ を求め、フィールド実験結果 や運動量理論を用いた単一流管理論により求めた数值と比 較した結果が図 4.1 である。全体的に見ると、数值シミュレ ーションによる周速比と風車効率の変化傾向は、単一流管理 論による結果と類似しており、フィールド実験結果からも大 きな乘離はない。このように数值シミュレーションにより求 めた風車効率はフィールド実験結果に対して良好な整合性 となった。 


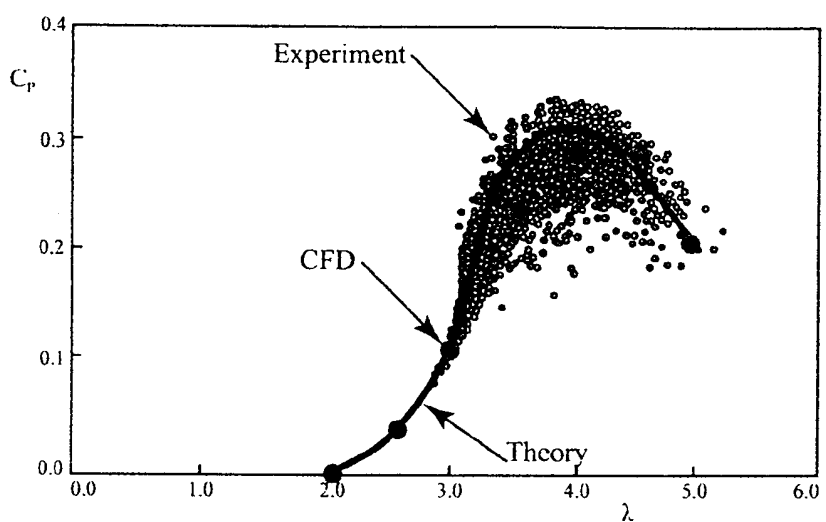

Fig.4.1 Performance calculation by experiment and CFD

また、数値シミュレーションにより風車周りの流れの性状 を解析し、風車性能研究に役立てている。作成している解析 結果の拔粋を図 4.2 に示した。

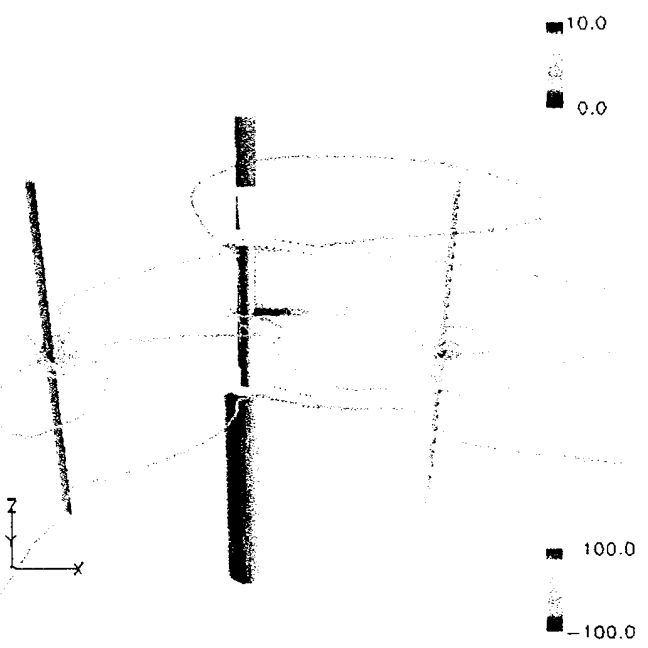

(a) tip speed ratio $=2.0$

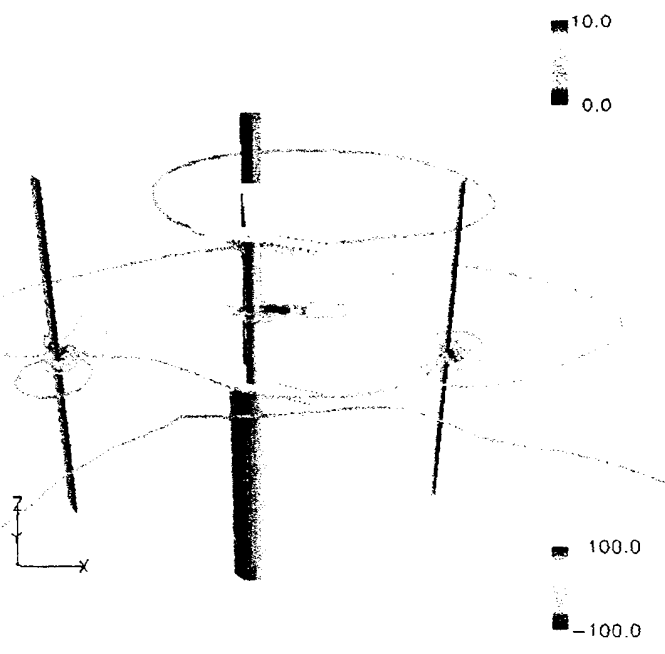

(b) tip speed ratio $=4.0$

Fig.4.2 Sample of the flow analysis around SW-VAWT by CFD
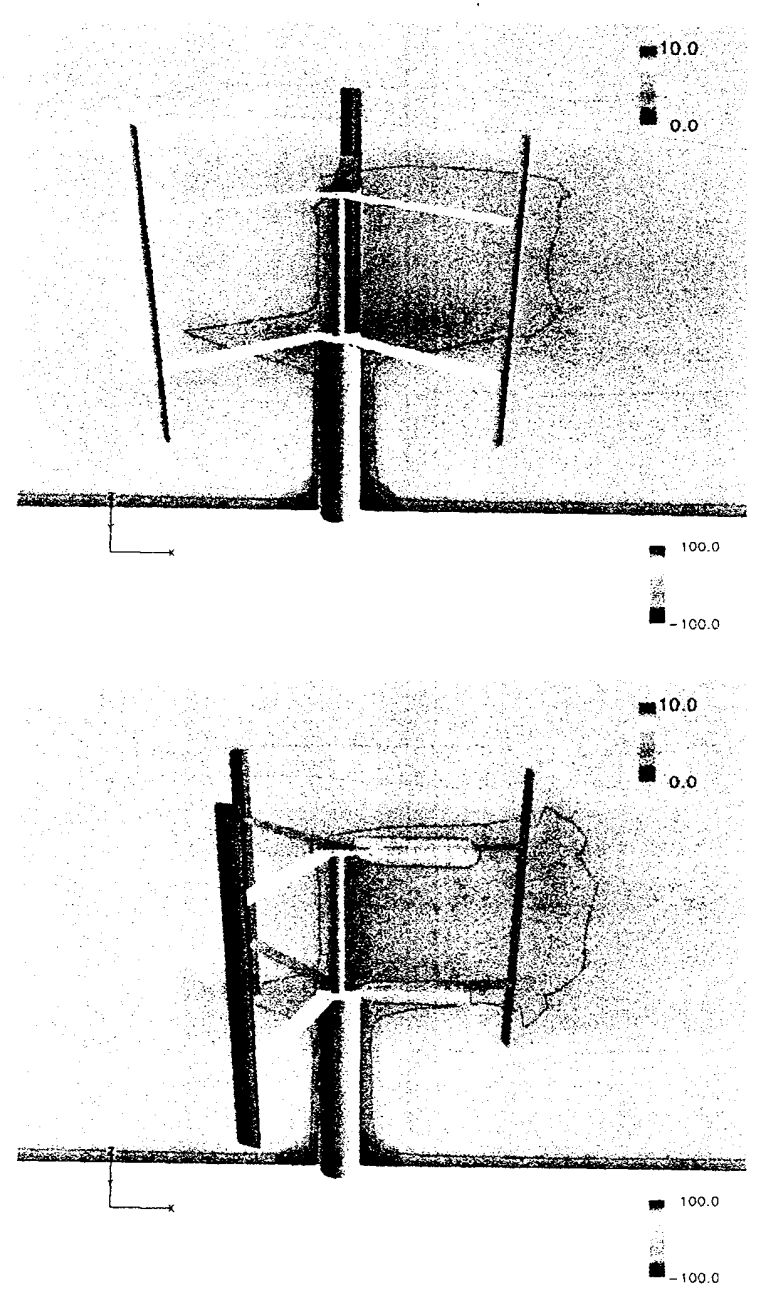

Fig.4.3 Sample of the flow analysis around SW-VAWT by CFD

\section{5. 結雚}

本研究は直線翼垂直軸風車発電システムについて、次のよ うなことか明示された。

1）直線翼垂直軸型風車の特徽が明らかになった。

2）直線翼垂直軸型風車の作動原理が明らかになった.

3）直線翼垂直軸型風車の性能の影響を与える要素が明ら かになった。

4）态用実験および性能害験を行い、期待通りの性能と成果 が得られた。

5）風車性能や特性解析において CFD が一つの有効な手法 であることが明らかとなった。

\section{参考文献}

1）関：風力エネルギ一利用 (その変換原理)，太陽エネルギ 一(Vol. 19, No. 3), 1993

2）関他：直線翼垂直軸型風車用翼型の空気力学的研究，太 陽エネルギー(Vol. 16, No. 3)，1990，日本太陽エネルギー 学会.

3）関他：直線翼垂直軸型風車の性能, 太陽エネルギー (Vol.16, No. 3)，1990. 日本太陽エネルギ一学会.

4）関: 低レイノルズ数での高性能を示す垂直軸風車用翼型 の開発研究，日本機械学会論文集 (B 編) 57 巻 536 号, 1991 